\title{
The interaction of Universities with high-tech enterprises: commercialization of innovations
}

\author{
Irina Kalinina ${ }^{1, *}$, and Karina Chernitsova ${ }^{2}$ \\ ${ }^{1}$ Department of Theory of Management and Business Technologies, Plekhanov Russian University of \\ Economics in Moscow, Moscow, Russia \\ ${ }^{2}$ Department of Theory of Management and Business Technologies, Plekhanov Russian University of \\ Economics in Moscow, Moscow, Russia
}

\begin{abstract}
The dynamics of innovative development greatly depend on the efficiency of the processes employed in creating and organizing active small innovative businesses. In this area, universities, with their innovative infrastructure and collaborative arrangements with businesses that provide a synergistic effect, play an important role. The goal is to substantiate the recommendations for commercializing the results of intellectual activities using networking mechanisms of interaction between universities and high-tech enterprises. The methods employed include process modeling and $\mathrm{ABC}$-analysis, as well as a systematic approach to the networking of universities and enterprises producing high-tech products. The model for the processes of commercializing innovations with the participation of universities was based on the business design methodology. The article contains an analysis of the development state of small innovative enterprises, as well as prospects for the development of interactive network mechanisms between universities and high-tech enterprises. The article defines the special role played by universities in the process of commercializing innovations; proposes models of classification, and reveals the methods of approach to an organizational and economic model of collaboration between universities and enterprises producing high-tech products. The results of the study are intended for use by heads of universities, small enterprises in the field of innovation, as well as hightech enterprises.
\end{abstract}

\section{Introduction}

The interaction of universities with high-tech enterprises is the primary focus of attention of European researchers who are studying the participation of universities in the dissemination of innovative solutions from different perspectives. First, cooperation between universities and industry is increasingly being viewed as a means to enhance innovation through the exchange of knowledge [1]. In this case, structured relationships are effective in developing the concept of the university-industry-government triple helix [2-4].

In light of this, universities are relevant for high-tech enterprises as a source of

\footnotetext{
* Corresponding author: karinaaa2004@mail.ru
} 
knowledge and the ability to use scientific research and receive innovation support. In this regard, the work done by Thomas Clauss and Tobias Kesting show a significant effect of the interaction of management mechanisms with the achievement of common goals of universities and enterprises producing high-tech products [5].

The issue of finding solutions to the problem of having organizational borders that may limit the ability of companies to obtain the necessary access to the university R \& Ds is also an important aspect of this research. The transmission of the information on the results of the research acts as a demotivating factor for cooperation, especially with respect to networking [6-7]. In this case, public-private partnerships play an important role.

The interaction between universities and high-tech enterprises is economically beneficial to both parties, as long as they are able to obtain reliable information about changes in the university R \& D portfolios and identify on this basis the potential for cooperation. In this case, it is important not only to find common interests, but also to organize the monitoring and evaluation of joint research programs $[8,9]$.

The dynamics of the interaction can be assessed through quantitative analyses based on wavelet transforms [10].

The most promising form of interaction between universities and high-tech enterprises is networking in which researchers act as knowledge experts, carrying out task assignments as consultants and innovation intermediaries. Universities scholars working for practice communities are particularly involved in the development of multilateral initiatives, with the aim of choosing ways and mechanisms of cooperation between different players (universities, research organizations, industrial enterprises, innovation agents and the like) [11].

An example of the role of a modern university in the field of intellectual property management in the form of the entrepreneurial activity of researchers is presented in the form of a synergy model between researches, entrepreneurship and technology commercialization [12].

\section{Relevance of the research}

The pace of the implementation of innovation depends on the activity of the interaction of economic agents at different stages of the innovation cycle. Higher education institutions that ensure the distribution of their innovations in high-tech enterprises by organizing small innovative enterprises (SIE) play an important role in this process.

SIE activity is an important part of the policy of the Russian Government, which is taking drastic measures to establish and implement the scientific potential of universities, as well as increase the level of scientific and technical development.

An analysis of the distribution of university developments in critical technologies, shown in Table 1, showed that sectors like digital manufacturing, mechanical engineering, nano - and microtechnology account for the major share (95 per cent). This indicates the orientation of university activities to the priority areas of high-tech development (Figure 1). 


\section{The number of research units}

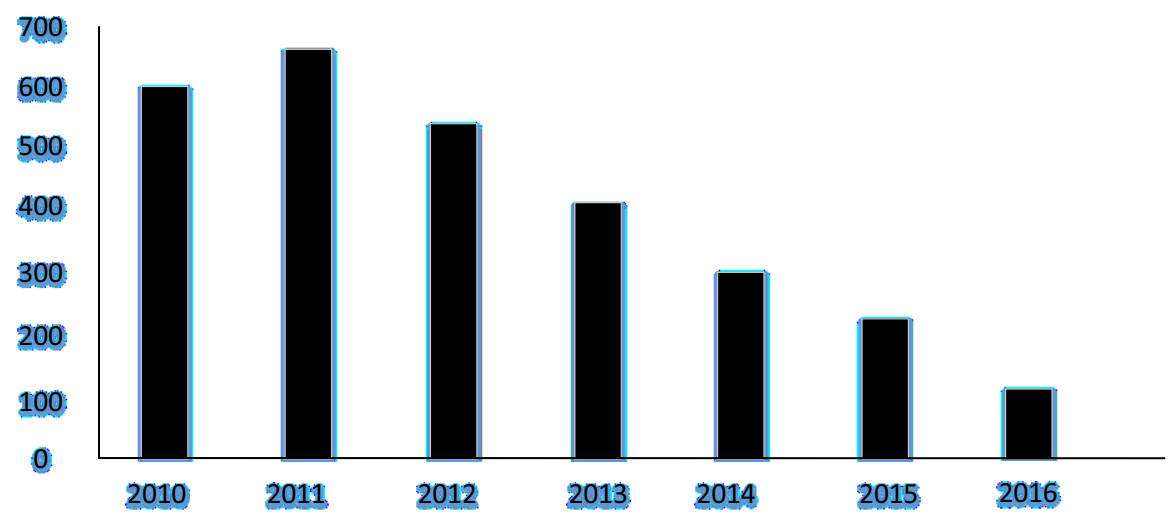

Fig. 1. Distribution of university developments in critical technologies (According to 2015 data)

The indicators for the distribution of university research developments based on stages of readiness for production show that industrial production contributed only 5 percent.

The data indicate the need to strengthen the role of the distribution of innovations in the work of university scientists. (Table 1, Figure 2).

Table 1. Distribution of university developments on critical technologies (according to 2015 data)

\begin{tabular}{|c|l|c|c|}
\hline Group & \multicolumn{1}{|c|}{ Description } & $\begin{array}{c}\text { Number of } \\
\text { developments, } \\
\text { units }\end{array}$ & $\begin{array}{c}\text { Percentage of } \\
\text { total }\end{array}$ \\
\hline 1 & Digital manufacturing & 507 & $31 \%$ \\
\hline 2 & Mechanical engineering & 363 & $22 \%$ \\
\hline 3 & Nano- and microtechnology & 283 & $17 \%$ \\
\hline 4 & Bioengineering & 236 & $14 \%$ \\
\hline 5 & Human safety and medicine & 141 & $9 \%$ \\
\hline 6 & Mineral resource exploration and extraction & 80 & $5 \%$ \\
\hline 7 & Nuclear power & 24 & $1 \%$ \\
\hline & TOTAL & 1634 & $100 \%$ \\
\hline
\end{tabular}

Calculated by the authors based on the data [13].

The main growth in the creation of SIEs by Russian universities took place in the period between 2010 and 2013. Presently, the growth potential has been exhausted. Moreover, many SIEs were abandoned without having been fully developed, while part of the registered SIEs either failed to proceed to launching into practice, or are currently demonstrating low performances.

In these circumstances, it becomes relevant to analyze the opportunities and find ways to improve the efficiency of higher educational institutions for the dissemination of innovations in cooperation with enterprises producing high-tech products. 


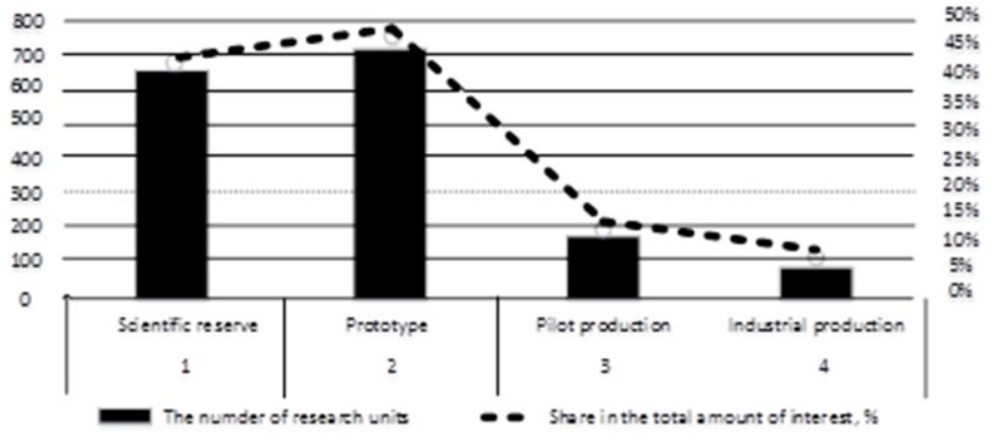

Calculated by the authors based on the data [13].

Fig. 2. Distribution of research developments of universities in stages of readiness for production (according to 2015 data)

The mechanism of interaction between universities and high-tech enterprises is based on a license agreement on the use of the intellectual deliverables (results of intellectual activity), which include the following results: computer programs; databases; inventions; utility models; - industrial designs; selective breeding results; topographies of integrated microcircuits; trade secrets (know-how). Thus, the exclusive rights to the intellectual deliverables (results of intellectual activity) are stored for further analysis by higher education institutions.

Research hypothesis consists of the following: the main problem in the interaction of university SIEs with high-tech enterprises is the insufficient demand for the SIEs' goods or services by industrial enterprises. A new networking model is required.

Research methodology. The methodological basis of the study served as a statistical analysis of the SIE data created within the universities, the systematic and structural analysis of the elements of the mechanism of interaction between universities, SIEs and companies, as well as a systematic analysis of the activities of universities in organizing research and developing innovative infrastructure.

Therefore, recommendations on improving the mechanism of interaction should be directed towards solving this problem, based on the development of university innovation infrastructure, that is, the creation of new units designed to be used in the commercialization of intellectual deliverables:

- technology transfer centers

- $\mathrm{R} \& \mathrm{D}$ commercialization departments

- intellectual property departments

- marketing centers

Such a change in the interaction of universities with high-tech enterprises requires changes in the organization of scientific research itself:

- focusing on purchasing power in the research topics;

- professional development of the levels of intellectual deliverable substantiation;

- increase of the level of readiness of scientific and research developments for practical use.

This contributes to the formation of new institutional models in the Russian scientific and educational sector. First, we note the allocation of national research centers and national research universities that are designed to become key centers of excellence on the global scientific and technological platform.

However, the following range of issues related to the establishment and functioning of SIEs at universities have to be resolved currently: 
- the development on the part of the university of special support measures compensating for the significant financial costs at the initial stage of development - lease payments, tax burden, purchase of equipment, materials and so on;

- the development in the university SIE of commercially-viable structural units of innovation infrastructure;

- the formation of a network model of interaction between the university SIE and enterprises producing high-tech products.

The networking model could primarily be focused on the scientific, technical and managerial capacity of the university SIE, which forms the organizational basis as an innovative link for scientific research organizations and companies. Within this context, the SIE shall act as the organizational basis for creating a separate institution (Single Institute Model), or in conjunction with the enterprises (Multi-Institute Model).

Network interaction is aimed towards full-scale implementation by participants of research and innovation projects as part of a long-term joint program to accelerate the commercialization of research developments by universities, with the implementation of the experience of their industrial partners.

The initial principles of effective interaction between universities and a high-tech enterprise should recognize the high commercial activity of the SIE, as well as the selffinancing of its activities.

The "elements of success" essential for a networking model are:

- availability of the scientific, technical, technological and resource potential of the networking participants, providing a competitive advantage;

- providing support to the management of scientific organizations;

- gaining access to various sources of financial support at different stages of the distribution of innovations;

- availability of a university leader of the commercialization process, as well as a team of professionals (well-rounded human resources);

- flexibility in the adoption and implementation of solutions, including issues on intellectual property, including its defense within the country and abroad, as well as the development of mechanisms for the commercialization of intellectual property;

- sufficient funding;

- practical experience in commercialization of the participants of the networking.

\section{Conclusion}

The study produced the following results:

- an analysis of the activities of Small Innovative Enterprises of Russian universities was conducted using an information and analytical system of monitoring the Small Innovative Enterprises of universities;

- an analysis of the interaction of Small Innovative Enterprises of universities and enterprises producing high-tech products was conducted;

- approaches to developing a model based on an example of the interaction of business entities with mechanical-engineering enterprises producing high-tech products were formulated and substantiated.

The research results make it possible to say that the following aspects need to be improved in the interaction process between universities and high-tech enterprises:

a. To stimulate the demand for developments offered by universities to commercialize them by enterprises. For this, first, it is possible to transfer to universities the right to independent disposition of dividends and incomes from participation in joint enterprises. This also applies to the possibility of the high-tech equipment transferring to joint use with universities. 
b. To support the innovation infrastructure of universities when preparing applications for various competition participations to attract the public and private investments. This aspect can, by means of partnership with universities, help high-tech enterprises to promote the results of their activities to the market, and promote the realization of their competitive advantages.

c. To develop technologies for the successful technology transfer from universities to high-tech enterprises through spin-off university companies, as well as to improve the transferring technology procedure from universities to industrial enterprises and companies, based on the realization of the right to sell licenses and assign patent rights.

\section{References}

1. S. Ankrah, O. AL-Tabbaa, Scandinavian Journal of Management, 31, Issue 3, 387-408 (2015)

2. V.V. Maslennikov, I.A. Kalinina, Mediterranean Journal of Social Sciences, 6. № 5 S4. 76-83 (2015)

3. M. Heitor, Original Research Article, Technological Forecasting and Social Change, 95, June 2015, 276-293 (2016)

4. V.V. Maslennikov, I.A. Kalinina, International Business Management, 9, 6. 1141-1146 (2015)

5. T. Clauss, T. Kesting, Industrial Marketing Management, In Press, Corrected Proof, Available online 20 September (2016)

6. M. Steinmo, E. Rasmussen, Journal of Business Research, 69, Issue 3, 1250-1259 (2012)

7. M. Perkmann, H. Schildt, Research Policy, 44, Issue 5, 1133-1143 (2015)

8. J. Ekboir, G. Blundo Canto, C. Sette, Evaluation and Program Planning, 61, $64-75$ (2017)

9. M. Simeth, J.D. Raffo, Research Policy 42, 1531-1543 (2013)

10. F. de Melo, V.V. Maslennikov, E.V.Popova, T.L. Bezrukova, I.V. Kyksova, Asian Social Science, 11. $20,66-73(2015)$

11. O. Alexy, G. George, A.J. Salter, Academy of Management Review, 38, 270-29 (2013)

12. J. G. Payumo, P. Arasu, A. M. Fauzi, I. Zulkarnaen Siregar, D. Noviana, World Patent Information, 36, 22-31 (2014)

13. http://inno-exp.ru/archive/16/innov_2016-1_145-151.pdf 